\title{
PENINGKATAN HASIL BELAJAR SISWA DENGAN MENGGUNAKAN \\ MODEL COOPERATIVE LEARNING TIPE CO-OP CO-OP DALAM \\ PEMBELAJARAN PKn KELAS V DI SDN 11 KOTO MARAPAK \\ KECAMATAN PARIAMAN TIMUR KOTA PARIAMAN
}

\author{
oleh \\ Rika Ramadani, Reinita, Zainal Abidin \\ Rikaramadani_86@yahoo.com,reinita_reinita@yahoo.com,zainal_awp@yahoo.co.id
}

\begin{abstract}
Abstrak
Penelitian bertujuan untuk meningkatkan hasil belajar PKn dengan menggunakan model cooperative learning tipe co-op co-op di kelas $\mathrm{V}$ SDN 11 Koto Marapak Kec.Pariaman Timur. Jenis penelitian adalah PTK, menggunakan pendekatan kuantitatif dan kualitatif.Hasil penelitian RPP siklus I rata-ratanya $72 \%$ meningkat pada siklus II menjadi $84 \%$. Pada aspek guru siklus I rata-ratanya $72 \%$ meningkat pada siklus II menjadi $90 \%$. Pada aspek siswa siklus I rata-ratanya $71 \%$ meningkat pada siklus II menjadi $82 \%$. Hasil belajar siswa siklus I rata-ratanya 74, dan pada siklus II meningkat menjadi 85 .
\end{abstract}

Kata kunci : Hasil Belajar; PKn; Model Cooperative Learning tipe Co-Op Co-Op

\begin{abstract}
The research aims to improve the learning outcomes of Civics by using cooperative learning model co-op co-op type in class V SDN 11 Koto Marapak Kec.Pariaman Timur. The type of research is PTK, using a quantitative and qualitative approach. The result of research of RPP of cycle I average $72 \%$ increase in cycle II to $84 \%$. In the teacher cycle aspect I average $72 \%$ increase in cycle II to 90\%. In the student aspect, the first cycle I is $71 \%$ increase in cycle II to $82 \%$. Student learning outcomes cycle I average 74, and on the second cycle increased to 85 .
\end{abstract}

Key Words : results of study;Civics; cooperative learning model co-op co-op type 


\section{PENDAHULUAN}

Mata pelajaran Pendidikan Kewarganegaraan (Pkn) merupakan salah satu mata pelajaran yang diajarkan di Sekolah Dasar (SD), yang merupakan program pendidikan yang memusatkan perhatian pada konsep, nilai, moral, norma, dan perilaku sesuai dengan Pancasila dan UUD 1945 serta hak dan kewajiban sebagai warga Negara, selain itu juga merupakan suatu wahana untuk mengembangkan dan melestarikan nilai luhur dan moral yang berakar pada budaya Bangsa Indonesia yang diharapkan dapat diwujudkan dalam bentuk perilaku kehidupan sehari-hari

Depdiknas ( 2006 : 271 ) yang menjelaskan bahwa “ Mata pelajaran Pkn di Sekolah Dasar (SD) merupakan mata pelajaran yang memfokuskan pada pembentukan warga Negara yang memahami dan mampu melaksanakan hak-hak dan kewajibannya untuk menjadi warga Negara Indonesia yang cerdas, terampil, dan berkarakter yang diamanatkan oleh Pancasila dan UUD 1945.”

Agar tujuan mata pelajaran Pkn tercapai, maka 1) Guru harus membuat Rencana Pelaksanaan Pembelajaran ( RPP ) yang baik, tepat dan terurut sebagai pedoman dalam proses pembelajaran, 2) Guru menggunakan sebuah model pembelajaran yang lebih mengaktifkan siswa, memberikan kesempatan pada siswa untuk bekerja sama, saling berbagi pemahaman dan bertanggung jawab terhadap pekerjaannya.

Berdasarkan pengamatan yang peneliti lakukan di SDN 11 Koto Marapak Kec Pariaman Timur Kota Pariaman, selama ini dalam proses pembelajaran PKn guru masih menggunakan paradigma yang lama yaitu teacher center dimana guru lebih dominan dari pada siswa, guru jarang memberikan kesempatan pada siswa bekerjasama dalam diskusi kelompok, kurang memberikan kesempatan pada siswa untuk mengeluarkan pendapat, dan tidak memberikan kesempatan pada siswa untuk tampil di hadapan teman- temannya. Hal ini disebabkan kurangnya keterampilan guru dalam memilih model pembelajaran yang tepat. Mereka mengharapkan siswa duduk, diam, dengar, catat dan hafal ( $\mathrm{D} 3 \mathrm{CH}$ ) sehingga siswa dalam pembelajaran Pkn itu merasa bosan. 
Akibat kurangnya keterampilan guru dalam memilih model pembelajaran yang tepat menyebabkan siswa tidak aktif dalam pembelajaran PKn, kurang termotivasi untuk mengeluarkan pendapat, tidak percaya diri dalam menyampaikan pemahaman baru dan tidak bertanggung jawab terhadap pekerjaannya. Hal ini berdampak pada hasil belajar yang diperoleh siswa yaitu nilai ujian Mid Semester I siswa kelas V tahun pelajaran 2016/2017 yang baru mencapai rata-rata 63,69.

Untuk mengatasi masalah tersebut, agar terwujud dan terlaksana pembelajaran Pkn sesuai dengan tujuan pembelajaran Pkn dan nilai yang diharapkan, maka diperlukan model pembelajaran yang tepat. Salah satunya model pembelajaran yang dapat diterapkan dalam pembelajaran Pkn adalah model pembelajaran kooperatif atau cooperatif learning. Slavin (2005:214) mengemukakan Co-Op Co-Op memberi kesempatan pada siswa untuk bekerja sama dalam kelompok-kelompok kecil, pertama untuk meningkatkan pemahaman tentang diri mereka dan dunia mereka, selanjutnya memberikan kesempatan pada mereka untuk saling berbagi pemahaman baru itu dengan teman - teman sekelasnya".

Dengan menggunakan model cooperative learning tipe co-op co-op siswa dapat menemukan dan memahami konsep yang terdapat pada mata pembelajaran Pkn di SD yang disampaikan oleh guru, siswa juga dapat belajar dari siswa lainnya serta mempunyai kesempatan pula untuk membelajarkan siswa yang lain. Dengan bekerjasama yang baik siswa dalam kelompok untuk memperoleh dan memberikan informasi yang diperlukan dalam menemukan dan memahami konsep yang dipelajari.

Secara umum penelitian ini bertujuan untuk mendeskripsikan peningkatan hasil belajar siswa dengan menggunakan model Cooperative Learning tipe Co-op Co-op dalam pembelajaran PKn kelas V Di SDN 11 Koto Marapak Kecamatan Pariaman Timur, Kota Pariaman. Secara khusus bertujuan untuk mendeskripsikan : 1) Rencanapelaksanaan pembelajaran ( RPP ) Pkn untuk peningkatan hasil belajar siswa dengan menggunakan Model Cooperative Learning Tipe Co-op Coop di kelas V SDN 11 Koto Marapak. 2) Pelaksanaan pembelajaran Pkn untuk 
meningkatkan hasil belajar siswa dengan menggunakan Model Cooperative Learning Tipe Co-op Co-op di kelas V SDN 11 Koto Marapak.Hasil belajar Pkn. 3) peningkatan hasil belajar siswa dengan menggunakan Model Cooperative Learning Tipe Co-op Co-opdi kelas V SDN 11 Koto Marapak.

\section{Metode Penelitian}

Penelitian ini menggunakan jenis penelitian tindakan kelas (PTK) dengan menggunakan analisis data kualitatif dan kuantitatif dengan subjek penelitian guru dan siswa kelas V SDN 11 Koto Marapak Kecamatan Pariaman Timur Kota Pariaman, yang terdaftar pada semester I tahun ajaran 2016/2017 dengan jumlah siswa 24 orang terdiri dari laki-laki 13 orang dan perempuan 11 orang. Penelitian ini menggunakan alurpenelitian tindakankelasSuharsimi,dkk(2009:74): "Secara garis besar terdapat empat tahapan yang dilalui,yaitu (1)perencanaan,(2) pelaksanaan,(3) pengamatan, dan (4) refleksi "

Data penelitianini berupa hasil pengamatan terhadap rencana pelaksanaanprosespembelajaranPkn dengan Model Cooperative Learning tipe Co-Op Co-Op, pelaksanaan pembelajaran PKn dengan Model Cooperative Learning tipe Co-Op Co-Op dan hasil peningkatan belajar siswa dari pembelajaranPkn dengan Model Cooperative Learning tipe Co-Op Co-Op padasiswakelasVSDN 11 Koto Marapak Kec. Pariaman Timur Kota Pariaman.

Untuk mengetahui kemampuan siswa dalam penguasaan materi dapat dilihat dari peningkatan hasil belajar masing-masing siswa di analisis dengan menggunakan data kuantitatif. Untuk penghitungan persentase dilakukan dengan menggunakan pendekatan kuantitatif yang dikemukan oleh Purwanto (2006:102):

Dengan rumus:

$$
\mathrm{NP}=\frac{\mathrm{R} \times 1}{\mathrm{SM}} 100 \%
$$

Keterangan:

$$
\begin{aligned}
& \mathrm{NP}=\text { Nilai persenyang dicari } \\
& \mathrm{R}=\text { =Skor mentah yang diperoleh siswa } \\
& \mathrm{SM}=\text { skor maksimum ideal tes yang bersangkutan } \\
& 100=\text { bilangan tetap }
\end{aligned}
$$


Kriteria keberhasilan siswa dan guru dapat dilihat dari besarnya presentasi keberhasilan yang diperolehnya. Menurut Aderusliana (dalam Taufik dan Muhammadi 2011:224) kriteriataraf keberhasilan adalah:

$$
\begin{aligned}
80 \%-100 \% & =\text { Sangat Baik } \\
70 \%-79 \% & =\text { Baik } \\
60 \%-69 \% & =\text { Cukup } \\
x<59 \% \quad= & \text { Kurang }
\end{aligned}
$$

\section{Hasil Penelitian}

\section{Siklus I Pertemuan I}

a) Perencanaan

Penggunaaan model Cooperative Learning Tipe Co-Op Co-Op dalam pembelajaran Mendeskripsikan Negara Kesatuan Republik Indonesia disusun dengan Indikator yang ingin dicapai adalah 1) Menjelaskan pengertian negara (kognitif), 2) Menyebutkan bentuk-bentuk negara (kognitif), 3) Menjelaskan bentuk dan sistem pemerintahan( kognitif), 4) Menunjukkan rasa cinta terhadap NKRI (afektif ), 5) Menemutunjukkan peta pulau- pulau besar di Indonesia ( psikomotor ).

Tujuan Pembelajaranyaitu (1) Dengan diskusi siswa dapat menjelaskan pengertian negara secara benar, (2) Dengan melakukan diskusi siswa dapat menyebutkan bentuk - bentuk negara dengan benar dan tepat, (3) Dengan melakukan diskusi, siswa dapat menjelasakan bentuk pemerintahan dengan benar, (4) setelah melakukan diskusi, siswa dapat menunjukkan rasa cinta terhadap NKRI, (5) Dengan melihat peta, siswa dapat menemutunjukkan peta buta pulau pulau besar di Indonesia dengan benar. Sedangkan materi pembelajaran pada siklus I pertemuan I ini yaituNegara Kesatuan Republik Indonesia (NKRI)

\section{b) Pelaksanaan}

Pelaksanaan dilakukan dengan melaksanakan kegiatan sesuai dengan apayangtelah direncanakan sebelumnya yaitu kegiatan awal, kegiatan inti dengan memasukkan langkah-langkah pembelajaran model cooperative learning tipe coop co-op, dan kegiatan akhir. 


\section{c) Pengamatan}

Hasil Pengamatan RPP siklus I pertemuan I, persentase $69 \%$ termasuk dalam kategori cukup. Pada aspek guru persentasenya adalah 68\%. Pada aspek siswa persentase skor rata-rata siklus I pertemuan I adalah 68\%. Hasil Belajar Siswa Siklus I Pertemuan Isecara klasikal diperoleh nilai rata-rata 69.Hasil penilaian aspek afektif pada siklus I pertemuan I secara klasikal adalah 73. Ratarata hasil penilaian aspek psikomotor pada siklus I pertemuan I adalah 69,2. Hasil belajar siswa keseluruhan setelah direkapitulasi dengan cara menggabungkan nilai kognitif, afektif dan psikomotor mendapatkan nilai rata-rata 70 dengan kriteria Baik

\section{d) Refleksi}

Hasil pengamatan yang diperoleh terhadap rencana pelaksanaan pembelajaran siklus I pertemuan I adalah $69 \%$ yang berarti masuk kategori cukup. Hasil pengamatan yang diperoleh terhadap aktifitas guru mencapai kriteria keberhasilan $68 \%$ yang berarti masuk kategori cukup. Hasil pengamatan yang diperoleh terhadap aktifitas siswa hanya mencapai kriteria keberhasilan $68 \%$ yang berarti masuk kategori cukup. Hasil belajar siswa yang merupakan hasil akhir siklus I pertemuan I diperoleh nilai rata-rata siswa 70 dan masih memperoleh kategori cukup. Secara klasikal siswa yang mencapai tingkat ketuntasan hanya $50 \%$ sedangkan tingkat ketuntasan kelas yang diharapkan adalah $75 \%$. Jadi siklus I pertemuan I belum berhasil dan dilajutkan ke pertemuan II

\section{Siklus I Pertemuan II}

\section{a) Perencanaan}

Standar Kompetensi dan Kompetensi dasar yang peneliti ambil sesuai dengan program semester Iyang sedang berlangsung yang mana standar kompetensinya adalah 1. Memahami Pentingnya Keutuhan Negara Kesatuan Republik Indonesia ( NKRI ) dan kompetensi dasarnya adalah 1.1 Mendeskripsikan Negara Kesatuan Republik Indonesia.Indikator yang ingin dicapai pada pembelajaran yang dilaksanakan pada siklus I pertemuan II ini adalah 1) Menjelaskan pengertian NKRI ( kognitif ), 2) Menyebutkan karakteristik wilayah NKRI ( kognitif ), 3) Menunjukkan rasa cinta terhadap 
NKRI (afektif ), 4) Membuat daftar provinsi beserta ibukota provinsi yang ada di Indonesia. (psikomotor).

Tujuan Pembelajaran,yaitu (1) Dengan diskusi, siswa dapat menjelaskan pengertian NKRI, ( 2) Melalui diskusi kelompok, siswa dapat menyebutkan karakteristik wilayah NKRI dengan benar, (3) Dengan melakukan diskusi, siswa dapat menunjukkan rasa cinta terhadap NKRI, (4) Melalui pengamatan terhadap peta, siswa dapat membuat daftar provinsi yang ada di Indonesia dengan benar dan tepat. Materi Pokok,yaituWilayah Negara Kesatuan Republik Indonesia (NKRI)

\section{b) Pelaksanaan}

Pelaksanaan dilakukan dengan melaksanakan kegiatan sesuai dengan apa yang telah direncanakan sebelumnya yaitu kegiatan awal, kegiatan inti dengan memasukkan langkah-langkah pembelajaran model cooperative learning tipe coop co-op, dan kegiatan akhir.

\section{c) Pengamatan}

Hasil Pengamatan RPP siklus I pertemuan II, persentase $75 \%$ termasuk dalam kategori baik. Pada aspek guru persentasenya adalah 75\%. Pada aspek siswa persentase skor rata-rata siklus I pertemuan II adalah 73\%. Hasil Belajar Siswa Siklus I Pertemuan I secara klasikal diperoleh nilai rata-rata 76.Hasil penilaian aspek afektif pada siklus I pertemuan II secara klasikal adalah 78. Ratarata hasil penilaian aspek psikomotor pada siklus I pertemuan II adalah 75. Hasil belajar siswa keseluruhan setelah direkapitulasi dengan cara menggabungkan nilai kognitif, afektif dan psikomotor mendapatkan nilai rata-rata 76 dengan kriteria Baik.

\section{d) Refleksi}

Berdasarkan hasil kolaborasi antara peneliti dan observer menunjukkan bahwa pelaksanaan proses pembelajaran menggunakan model cooperative learning tipe co-op co-op secara umum sudah terlaksana dengan baik. Namun masih banyak hal yang harus diperbaiki Hasil pengamatan yang diperoleh terhadap rencana pelaksanaan pembelajaran siklus I pertemuan II adalah $75 \%$ yang berarti masuk kategori baik. Hasil pengamatan yang diperoleh terhadap 
aktifitas guru mencapai kriteria keberhasilan $75 \%$ yang berarti masuk kategori baik. Hasil pengamatan yang diperoleh terhadap aktifitas siswa mencapai kriteria keberhasilan yaitu 73\% yang berarti masuk kategori baik. Hasil belajar siswa yang merupakan hasil akhir pertemuan II siklus I diperoleh nilai rata-rata siswa 77 dan memperoleh kategori baikDengan demikian proses pembelajaran dengan modelcooperative learning tipe $\mathrm{Co}-\mathrm{Op} \mathrm{Co}-\mathrm{Op}$ yang dilaksanakan oleh guru sudah baik, namun masih ada kekurangan-kekurangan, sehingga penelitian ini dilanjutkan ke siklus II.

\section{Siklus II}

\section{a) Perencanaan}

Standar Kompetensi dan Kompetensi dasar yang peneliti ambil sesuai dengan program semester Iyang sedang berlangsung yang mana standar kompetensinya adalah 1. Memahami Pentingnya Keutuhan Negara Kesatuan Republik Indonesia ( NKRI ) dan kompetensi dasarnya adalah 1.2 Menjelaskan pentingnya keutuhan negara kesatuan republik Indonesia. Indikator yang ingin dicapai pada pembelajaran yang dilaksanakan pada siklus II ini adalah 1) Menjelaskan sejarah Negara Kesatuan Republik Indonesia ( kognitif ), 2) Menyebutkan alasan pentingnya menjaga keutuhan NKRI (kognitif ), 3) Mengidentifikasi gangguan terhadap NKRI ( kognitif ), 4) Memberikan contoh sikap menjaga keutuhan NKRI ( afektif ), 5) Membuat tabel daftar suku - suku yang ada di provinsi Indonesia ( pikomotor)

Tujuan Pembelajaran,yaitu 1) Dengan diskusi siswa dapat menyebutkan arti pentingnya menjaga keutuhan negara kesatuan republik Indonesia dengan benar. 2) Dengan melakukan diskusi siswa dapat menyebutkan alasan pentingnya menjaga keutuhan NKRI dengan benar. 3) Dengan diskusi siswa dapat mengidentifikasi gangguan terhadap NKRI dengan benar. 4) Dengan diskusi siswa dapat memberikan contoh sikap menjaga keutuhan NKRI dengan tepat. 5) Dengan penugasan siswa dapat membuat tabel daftar suku - suku yang ada di Indonesia. Materi Pokok, yaitu Keutuhan Negara Kesatuan Republik Indonesia (NKRI). 


\section{b) Pelaksanaan}

Pelaksanaan dilakukan dengan melaksanakan kegiatan sesuai dengan apayangtelah direncanakan sebelumnya yaitu kegiatan awal, kegiatan inti dengan memasukkan langkah-langkah pembelajaran model cooperative learning tipe coop co-op, dan kegiatan akhir.

\section{c) Pengamatan}

Hasil Pengamatan RPP siklus II persentase $84 \%$ termasuk dalam kategori sangat baik. Pada aspek guru persentase skor rata-rata siklus II adalah 90\%. Pada aspek siswa persentase skor rata-rata siklus II adalah 82\%. Hasil Belajar Siswa Siklus IIsecara klasikal diperoleh nilai rata-rata kognitif 86. Hasil penilaian aspek afektif pada siklus II secara klasikal adalah 88. Rata-rata hasil penilaian aspek psikomotor pada siklus II adalah 80. Hasil belajar siswa keseluruhan setelah direkapitulasi dengan cara menggabungkan nilai kognitif, afektif dan psikomotor mendapatkan nilai rata-rata 85 dengan kriteria Sangat Baik.

\section{d) Refleksi}

Pembelajaran Pkn pada siklus II dengan materi menjaga keutuhan NKRI dengan model cooperative learning tipe ico-op co-op di kelas V SDN 11 Koto Marapak Kecamatan Pariaman Timur telah berhasil dengan sangat baik. Terbukti dengan hasil yang didapat baik dari pengamatan terhadap RPP, guru, dan siswa telah meningkat dibanding dari siklus I.

\section{PEMBAHASAN}

\section{Pembahasan Siklus I}

\section{a) RPP}

Dari hasil penelitian pelaksanaan pembelajaran dengan menggunakan model Cooperative Learning tipe co-op co-op pembelajaran Pkn di kelas V diketahuibahwa hasil penilaian observer terhadap kemampuan guru merancang rencana pelaksanaan pembelajaran pada siklus I pertemuan I belum berhasil, dimana jumlah skor yang diperoleh adalah 22 dari jumlah maksimal 32, dengan rata-rata 69. Hal ini terjadi karena guru kurang jelas dalam merumuskan pembelajaran, pemilihan materi belum dapat mengembangkan kemampuan berfikir kritis pada siswa dan membuat siswa belajar lebih aktif, serta meransang 
keterlibatan siswa untuk belajar. Menurut Supriyadi (1995:159) "Sebelum melaksanakan tindakan, guru dituntut membuat perencanaan karena yang akan dihadapi dalam pelaksanaan tindakan adalah manusia yang siap tumbuh dan berkembang penalaran, sikap, dan tingkah lakunya". pada siklus I pertemuan kedua sudah ada peningkatan yaitu 75, dimana jumlah skor yang diperoleh adalah 24 dari jumlah skor maksimal 32. Jadi rata-rata RPP pada siklus I adalah 72.

\section{b) Pelaksanaan Pembelajaran}

Pelaksanaan pembelajaran dengan menggunakan model cooperative learning tipe co-op co-op siklus I dilakukan di kelas V SDN 11 Koto Marapak Kecamatan Pariaman Timur Kota Pariaman pada pembelajaran Pkndikatakan belum sepenuhnya berhasil karena siswa belum terbiasa dengan menggunakan model pembelajaran cooperatif learning tipe co-op co-op dalam pembelajaran. Hal ini membuat siswa canggung, dan antusias siswa dalam belajar belum terlihat, kerjasama dalam kelompok masih bingung dengan apa yang akan dilakukan dalam diskusi kelompok, akibatnya partisipasi siswa dalam kelompok menjadi rendah. Model Cooperative Learning tipe co-op co-op mengharapkan siswa dapat saling bekerjasama dan menjadikan pembelajaran menjadi menyenangkan.

Berdasarkan diskusi peneliti dengan observer, pelaksanaan pembelajaran dengan menggunakan model Cooperatif Learning tipe co-op co-op aspek guru dan siswa dikatakan baik.Hal ini dapat dilihat pada rata-rata aspek guru pertemuan I adalah 68 dan pertemuan II adalah 75.Jadi rata-rata aspek guru pada siklus I adalah 72. Sedangkan aspek pada siswa rata-rata pertemuan I adalah 68 dan pertemuan II 73. Jadi rata-rata aspek siswa pada siklus I adalah 71.

\section{c) Hasil Belajar}

Dari hasil penelitian siklus I, hasil belajarpenelitiansiklusI pertemuanI nilairata-rata siswa secara keseluruhan mencapai 70 . Dimana rata-rata nilai kognitif adalah 69, rata-rata nilai afektifnya adalah 73 dan rata-rata nilai psikomotor adalah69.Sedangkan untuk siklus I pertemuan II sudah ada peningkatan. Ini terlihat dari rata-rata hasil belajar siswa secara klasikal yangmencapai7 7 , dimana rata-rata nilai kognitifnya adalah 76 , rata-rata nilai afektif 78 dan psikomotor 75 . 
Berdasarkan rekapitulasi hasil belajar siswa pada siklus I ini bisa dikatakan hasil belajar siswa dengan menggunakan model Cooperative Learning tipe CoOp Co-Opdi kelas V SDN 11 Koto Marapak, Kecamatan Pariaman Timur secara klasikal sudah hampir mencapai KKM yang telah ditetapkan yaitu 75, dimana hasil rekapitulasi belajar siswa pada siklus I pertemuan I dan II rataratanya adalah 74. Untuk itu, siklusIperlu dilanjutkan kesiklus II.

\section{Pembahasan Siklus II}

\section{a) RPP}

Dalam penelitian siklus II ini peneliti telah berusaha memperbaiki komponen yang terdapat dalam RPP. Deskriptor yang tidak muncul pada siklus I sekarang sudah ada yang muncul seperti kejelasan perumusan tujuan pembelajaran tidak menimbulkan penafsiran ganda dan pengorganisasian materi ajar sesuai dengan sistematika materi pembelajaran. Berdasarkan hasil penelitian jumlah deskriptor yang muncul pada siklus II ini sudah meningkat yaitu 27 dari 32 deskriptor sehingga rata-ratanya menjadi 84 dengan kualifikasi sangat baik (SB). Guru membuat rancangan pembelajaransesuai dengan komponen RPP yang diterangkan oleh Depdiknas (2006:163) yang menjelaskan bahwa "komponen rencana pelaksanaan pembelajaran minimal mencakup: 1) standar kompetensi, 2) kompetensi dasar, 3) indikator, 4) tujuan pembelajaran, 5) materi pembelajaran, 6) langkah pembelajaran, 7) sumber dan media, 8) metode pembelajaran dan pendekatan, 9) penilaian pembelajaran. Standar kompetensi dan kompetensi dasar diambil dari kurikulum tingkat satuan pendidikan Pkn kelas V sekolah dasar.

\section{b) Pelaksanaan Pembelajaran}

Pelaksanaan pembelajaran dengan menggunakan model cooperatif learning tipe co-op co-op aspek guru dan siswa dikatakan sangat baik. Hal ini dapat dilihat pada rata-rata aspek guru pada siklus II adalah 90. Sedangkan rata-rata aspek siswa adalah 82 .

\section{c) Hasil Belajar}

Berdasarkan hasil penelitian hasil belajar siswa di dapat dari hasil tes pengetahuan, sikap dan keterampilan. Dari hasil penelitian siklus II, nilair ata-rata 
siswa secara keseluruhan mencapai 85. Dimana rata-rata nilai kognitif adalah 86, rata-rata nilai afektifnya adalah 88 dan rata-rata nilai psikomotor adalah 80 .

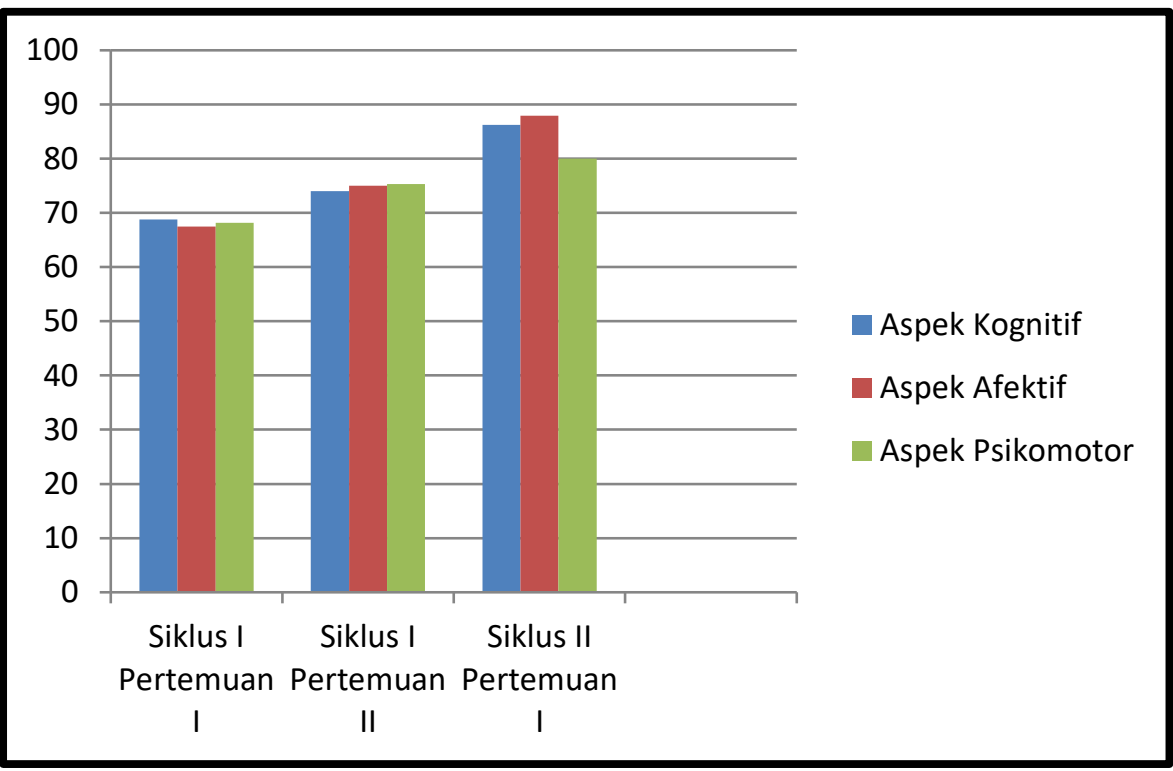

Dari grafik diatas terlihat jelas bahwa setiap pertemuan,terjadi peningkatan rata-rata hasil belajar siswa, terlihat siklus I pertemuan I rata- rata hasil belajar siswa 70 dan siklus I pertemuan II hasil belajar siswa 76. Dan pada siklus II pertemuan I rata-rata hasil belajar siswa 85 . Hasil tindakan pada siklus II ini sudah mencapai target yang diinginkan dan peneliti sudah berhasil dalam meningkatkan pembelajaran PKn siswa kelas V SDN 11 Koto Marapak Kecamatan Pariaman Timur Kota Pariaman terutama pembelajaran mendeskripsikan wilayah NKRI. Sesuai dengan Kriteria ketuntasan menurut BSNP (2006:12) adalah:

$$
\begin{aligned}
& 75 \%-100 \%=\text { Tuntas } \\
& 0 \%-74 \%=\text { Belum Tuntas }
\end{aligned}
$$

Dari pendapat di atas dapat disimpulkan bahwa pembelajaran pada siklus II ini sudah bisa dikatakan tuntas karena rata-rata yang diperoleh berada diantara $75 \%-100 \%$.

\section{SIMPULAN DAN SARAN}

RPP dengan menggunakan model cooperative learning tipe co-op co-op disusun dalam bentuk RPP dan memasukkan langkah-langkah model cooperative 
learning tipe co-op co-op. Pelaksanaan pembelajaran materi Keutuhan Negara Kesatuan Republik Indonesia di kelas V SDN 11 Koto Marapak Kecamatan Pariaman Timur Kota Pariaman sudah terlaksana sesuai dengan langkah-langkah model cooperative learning tipe co-op co-op yaitu 1) diskusi kelas yang terpusat pada siswa, 2) seleksi dan pembentukan kelompok, 3) seleksi topik kelompok, 4) seleksi mini topik, 5) persiapan mini topik, 6) Presentasi mini topik, 7) persiapan presentasi kelompok, 8 ) presentasi kelompok, 9 ) Evaluasi. Berdasarkan hasil belajar terbukti model cooperative learning tipe co-op co-op dapat meningkatkan hasil belajar siswa dalam pembelajaran Pkn di kelas V SDN 11 Koto Marapak Kecamatan Pariaman Timur Kota Pariaman

Berdasarkan kesimpulan, dapat disarankan : 1) untuk peneliti selanjutnya dapat menerapkan cara pembelajaran dengan menggunakan langkah-langkah model cooperatif learning tipe co-op co-op di sekolah nanti, 2) bagi guru hendaknya model cooperatif learning tipe co-op co-op dapat dijadikan sebagai salah satu alternatif dalam pembelajaran PKn dan sebagai suatu model yang dapat digunakan untuk meningkatkan hasil belajar siswa., 3) bagi Kepala Sekolah dapat memudahkan dalam memberikan bimbingan kepada guru dan dapat memberikanperhatiankepadagurudalammeningkatkanhasil belajar siswa, 4) bagi siswa hendaknya dapat termotivasi belajar dengan menggunakan model cooperatif learning tipe co-op co-op dan melatih keaktifan siswa dalam belajar, serta merangsang siswa untuk aktif mengembangkan potensinya dalam proses pembelajaran di sekolah dasar.

\section{Daftar Rujukan}

Depdiknas. 2006. Standar Kompetensi Pkn kelas V. Jakarta:Dikdasmen

Kunandar.2011.Langkah Mudah Penelitian Tindakan Kelas Sebagai Pengembangan Profesi Guru.Jakarta: Raja Grafindo Persada

Nur Asma.2008. Model Pembelajaran Kooperatif. Padang : UNP Pers

Slavin, Robert 2005. Cooperatif Learning Teori, Riset dan Praktik. Bandung: Nusa Medi

Suharsimi Arikunto.2007.Penelitian Tindakan Kelas.Jakarta : Bumi Aksara 